Historic, Archive Document

Do not assume content reflects current scientific knowledge, policies, or practices. 



\section{W. W. WILMORE}

DAHLIA SPECIALIST

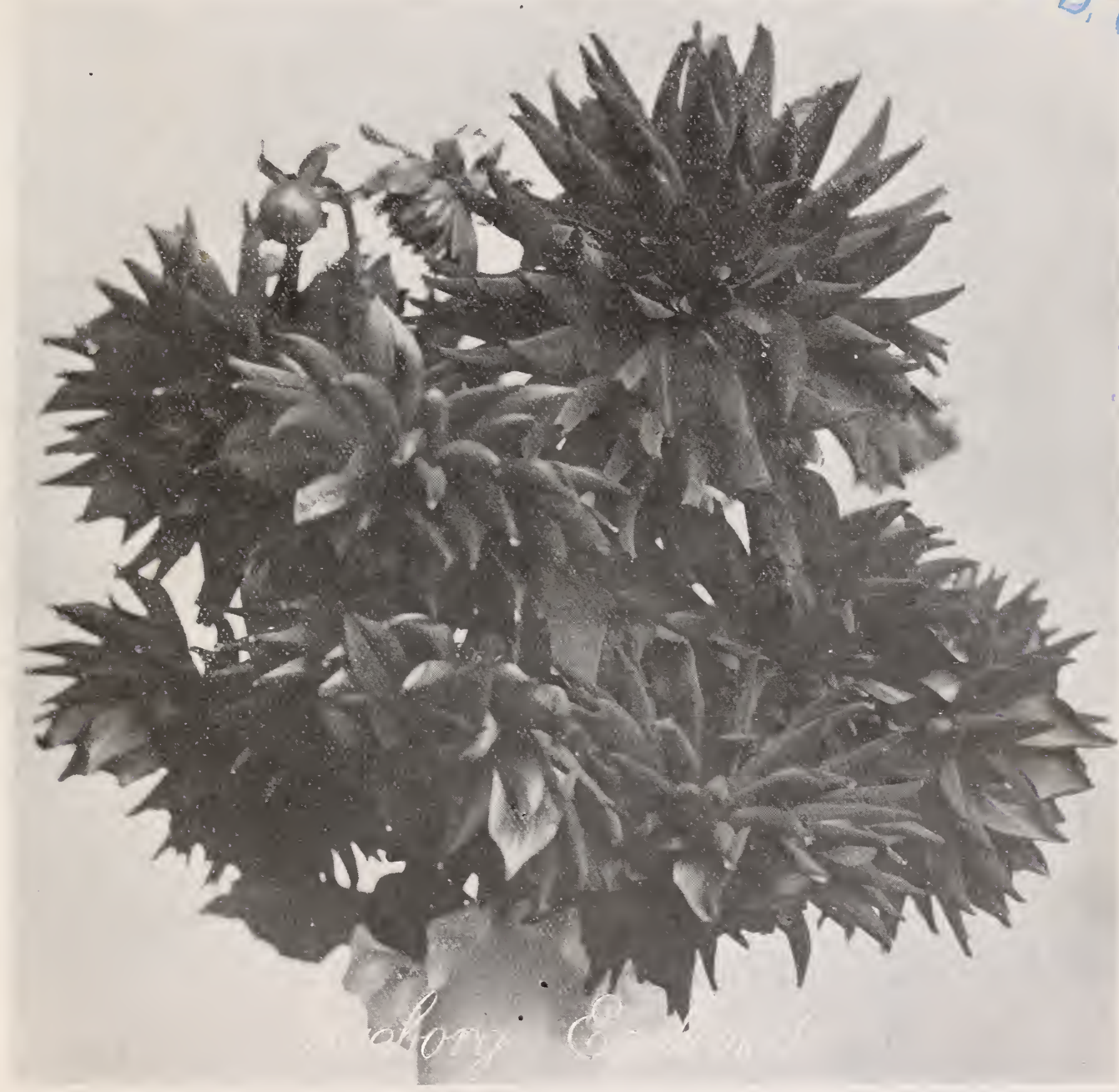

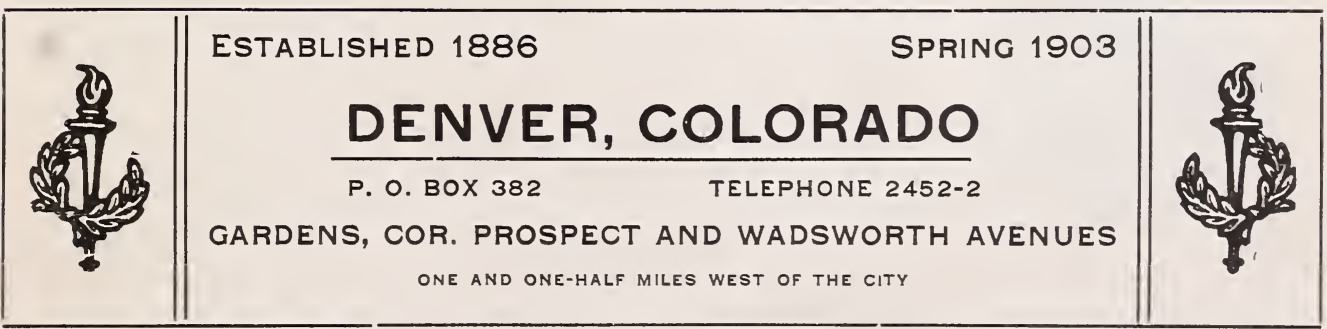




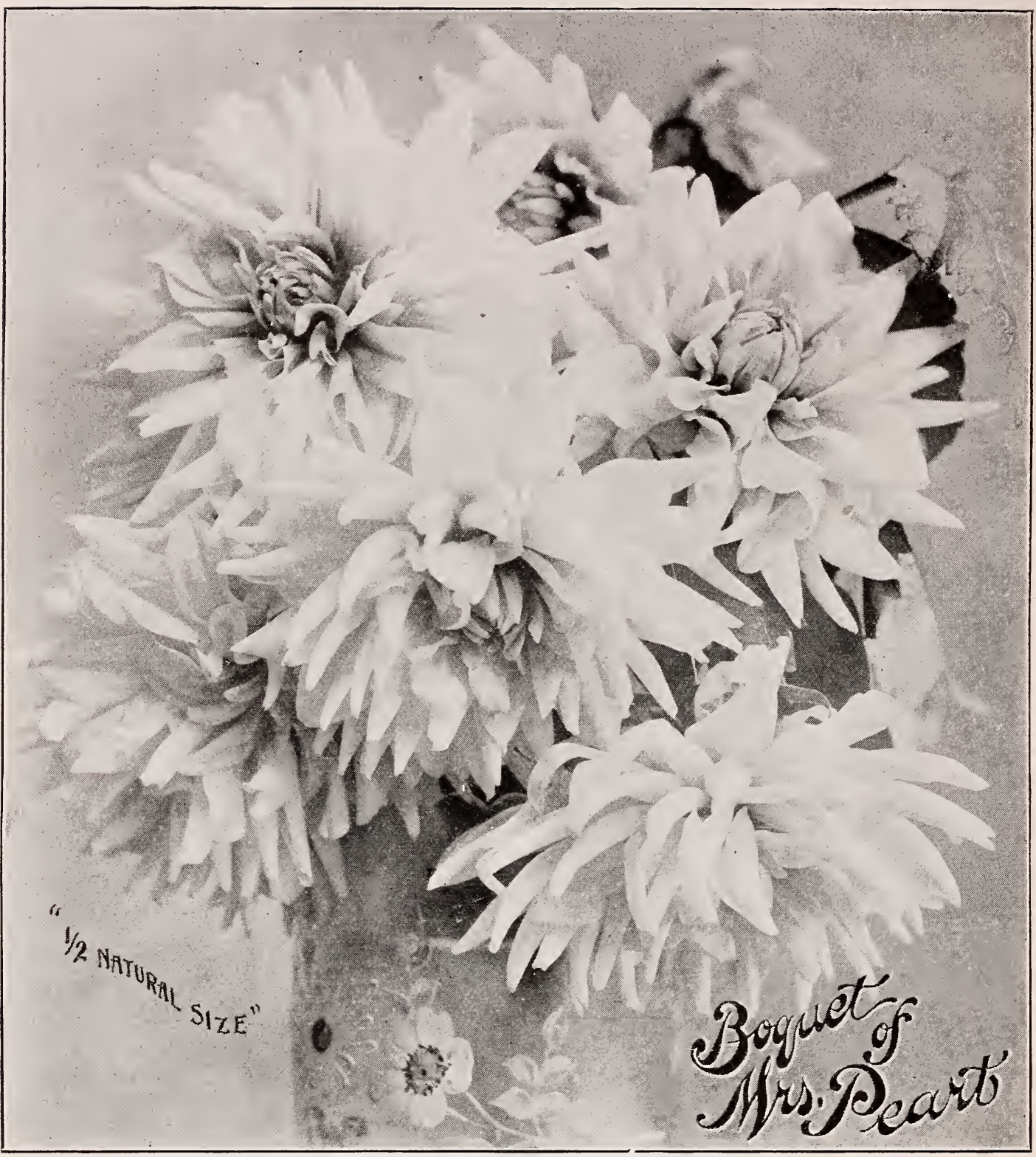

PRICES

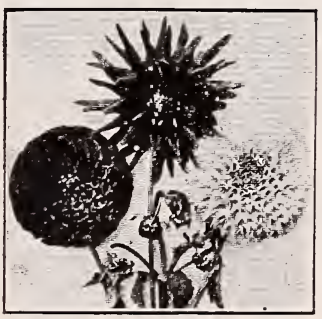

I do not claim that $\mathrm{my}$ prices are the lowest; nor have I ever coveted the reputation of rumning a "cheap place." I-aim to do an honest business and at the same time retain a profit on $\mathrm{my}$ investments. The present evolutionary period of the Dahlia requires the purchasing of new and costly rarieties, and the discarding of many hitherto good varieties and subsequent loss and waste of stock. Many of the best varieties are shy producers of tubers. Nerertheless, my prices will be found quite reasonable and even lower than others. Special attention of patrons is called to the list of Hardy Herbaceous Plants. They thrive almost anywhere that a weed would grow, requiring only reasonable care the first year to get them well established. I will gladly make selections for those not familiar with hardy plants if they will inform me as to space to be filled. In this way I can send thirteen distinct varieties, postpaid, for $\$ 1.00$. 


\section{Highest National Honors}

My display of Dahlias at the Great Exposition was the only one that received a prize. Owing to the great distance I hare nerer competed in eastern shows, but when a prize is offered within one thousand miles of me my prize winners have nerer failed to bring the prize my way. They will do the same for you.

"Your exhibit was a good one and I am sure attracted sufficient attention to thoroughly repay you for having it."-From F. W. Taylor, Supt. Dept. of Exhibits.
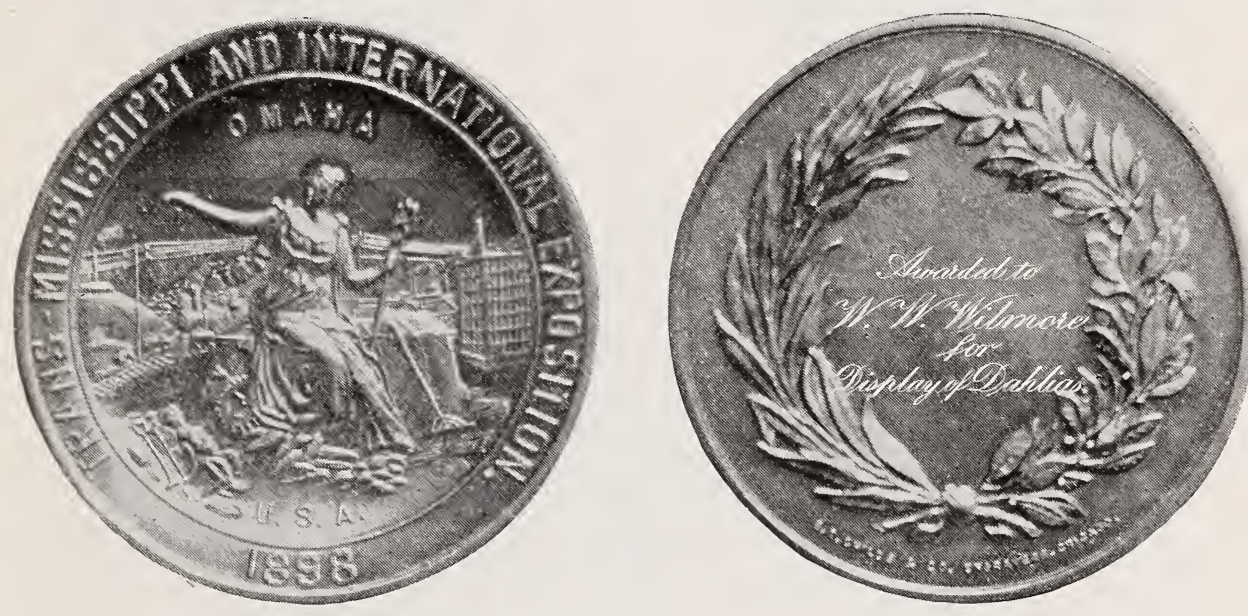

\section{FRIENDS AND PATRONS}

\section{GREETING}

It is fitting and proper that in presenting my Catalogue for the new year, I gratefully acknowledge the farors received at the hands of my friends and patrons in the past. By their cordial support 1 have attained to the position of the largest Dahlia Specialist in the United States. The wonderful progress and improrement made in this popular flower in the past few years has necessitated a rigid weeding out of inferior as well as many heretofore considered good rarieties. By this careful attention to business I have kept to the front, and have never failed in taking the first premium of the State. Customers ma select from my lists with the assurance that the stock will be the best, and that the rarieties will be true to name and color. Each year I originate many new rarieties, and carefully note in a book kept for that purpose the habits and qualities of each rariety. The stock offered in this Catalogue represents sixteen years of careful study and selection of varieties. To all those who receive this Catalogue, and have never tested my stock, I solicit a trial order, feeling confident that the stock will prove entirely satisfactory. 

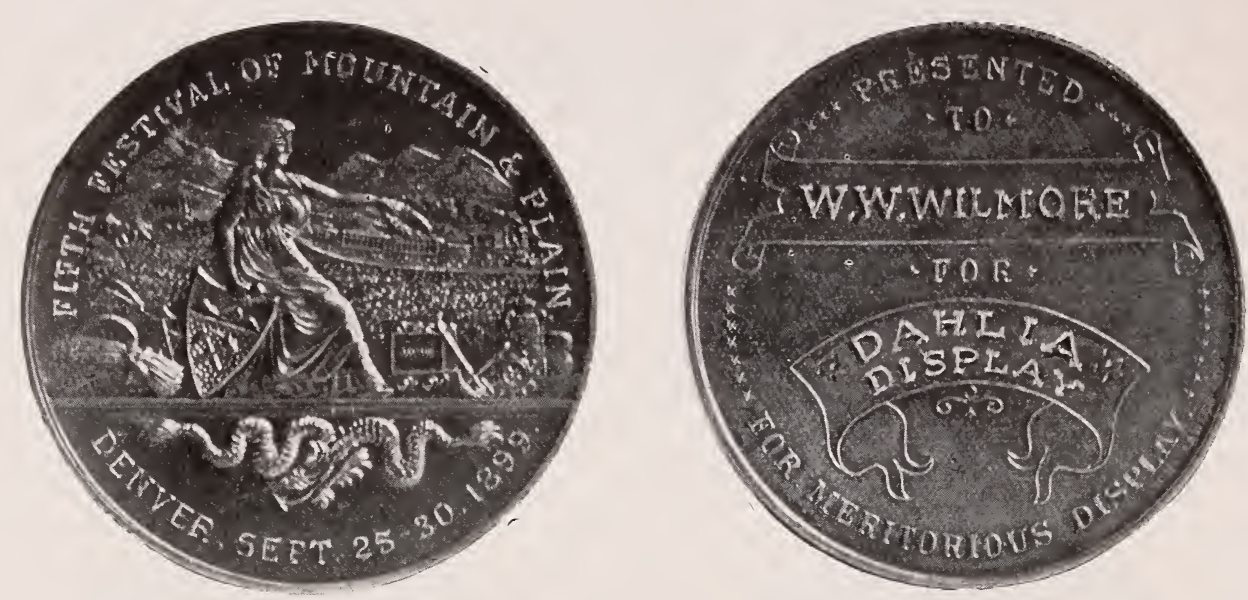

\section{TERMS Unor wact to BUSINESS}

First-The cash must accompany the order.

Second-Remittances may be sent in any way most convenient to the purcharer, but where remittances are made by $\mathrm{P}$. O. order or registered letter extra stock will be given to recompense for the extra cost.

Third-Prices quoted include postage or express charges to all portions of the Cnited states and Canada when purchased at retail, except where noted.

Fourth-C!ub Terms: In lots of five dozen or over to one address, those varieties priced at $\$ 1.50$ per dozen will be sent for $\$ 1.25$; all other stock in proportion.

Fifth-one-lalf dozen may be ordered at dozen rates. An "Extra" is sent with all orders, including half-dozen orders.

Sixth-*Guarantee: I guarantee my stock true to name, and of perfect germinating qualities. with the express understancine that should any not prove so, I will replace it with other stock. or refund the money paici, lut will not be liable for any damage beyond this.

*Roses. shrubs and vines are not included in the above guarantee.

\section{How to Order}

It would be well for each prirchaser, when making out an order, to name several varieties as a second choice, for the reason that some of the varieties wanted may be out of stock when the orcier reaches me.

CAPE MaY, N.J.

"I write to tell you of my rery flattering success with the Dahlias I purchased of you. Since August the 1st they have been a blaze of color. Stock all grew and are among my strongest varieties." O. H. BROWN
San Francisco, Cala.

"All the Dahlias I ordered, bloomed, and I am more than delighted with them. I think MIrs. Peart alone is worth more than I paid for the lot.

E. L. MAY. 


\section{NOVELTIES $S$ AND DAHLIAS OF}

INGEBORG EGELAND. (See Page 1). A glance at the half-tone eut on first page will reveal more of the beaty of this grand, new cactus Dahlia than words can tell. I feel secure in the statement that with it many points of excellence it is easily the first Dahlia in its class. I have had it muler severe eritical tests for several years, and find it the queen of its class.

One specimen in the bouquet from which the illustration was made measured $71 / 4$ inches in diameter. Its color is a most intense searlet, without shading or vilriation. Petals are long and pointed, presenting a model of perfection. The plant is compact and erect in growth, with flowers well above the foliage on stifi, nedium length stems. An early and profuse bloomer.

Stock quite limited: strong tubers, $\$ 1.00$ each.

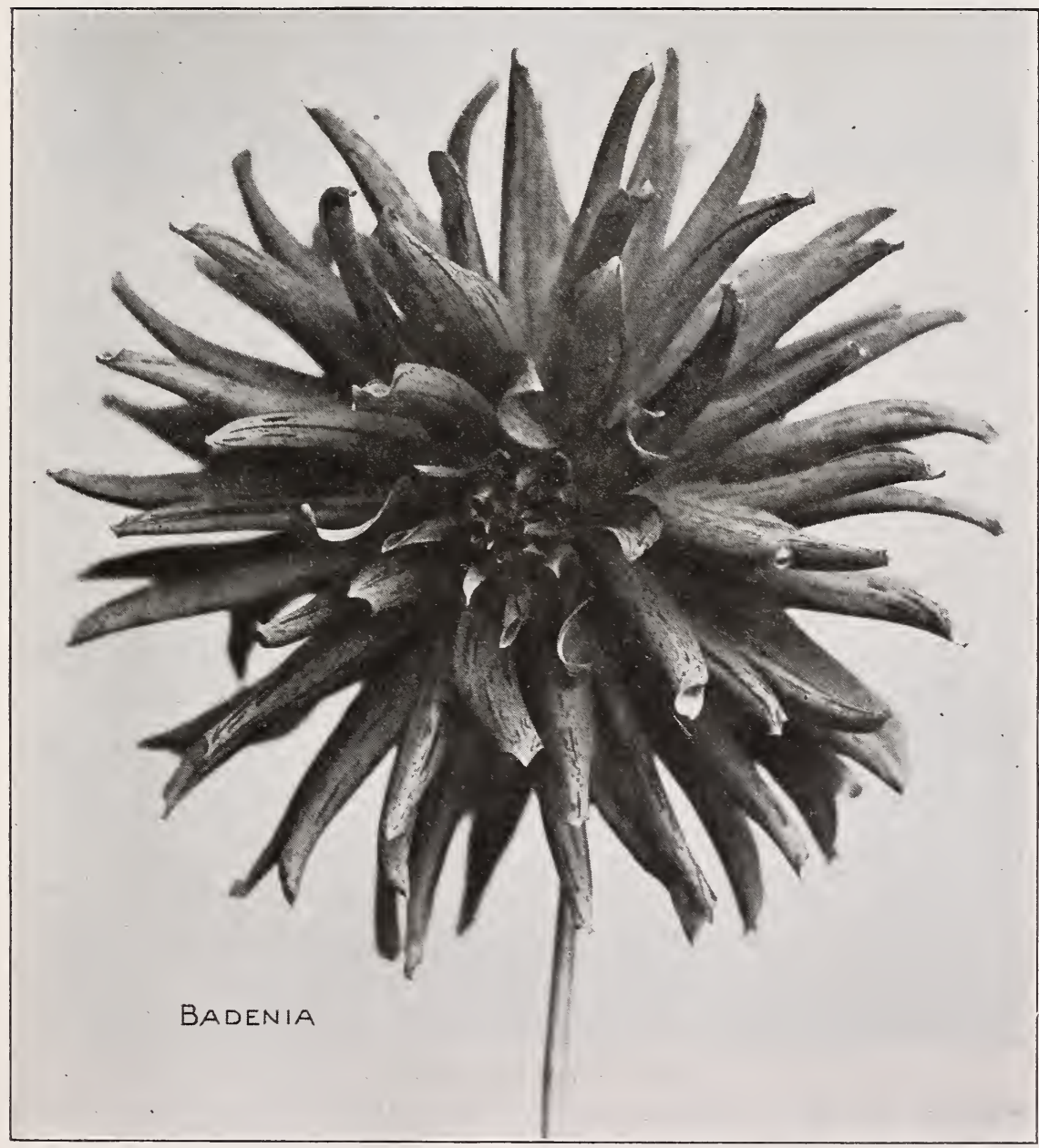

BADENIA. In this grand Dahlia we have the first really rariegated Dahlia in the cactus section. Color a clear bright orange, striped and flecked with bright red. Petals are rery long, and curved towards the center. Flowers are large. and the plant an erect, robust grower. A glance at the iliustration will show the form to be a model of verfection.

I have but a few tubers on sale this year. Price, 3.5e each. $\$ 3.50$ per dozen. 


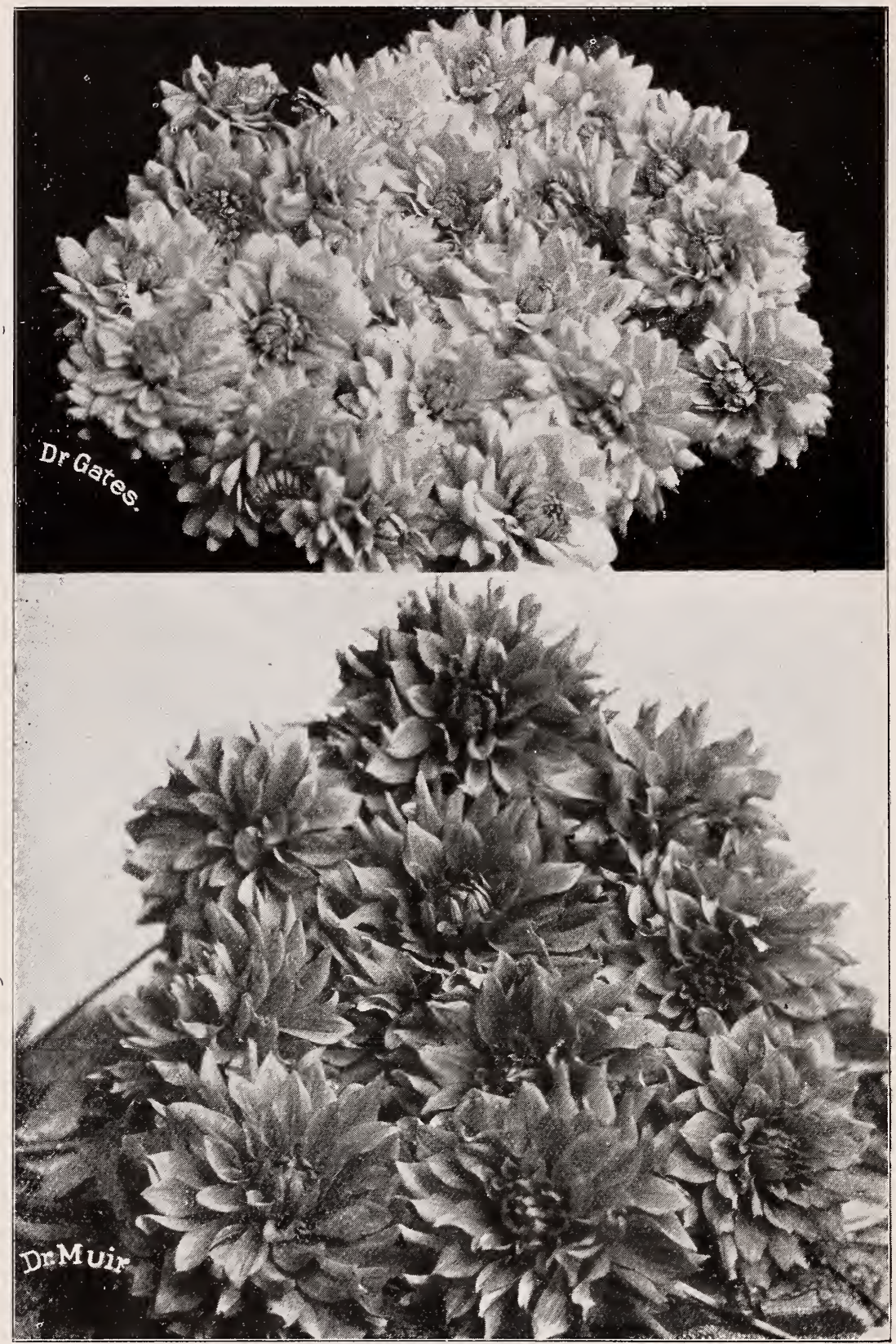

SIZE REDUCED THKEE-HUUKTHS

DR. GATES. (1902)-This new cactus Dahlia is a lovely shade of sea shell pink shading to blush at the base of the petals. Unlike so many of the cactus varieties, this one has a fine stem, holding its flowers well above the foliage. Its flowers are very even in size and form. As a variety for cutting it has no equal among the cactus types; a noble Dahlia.

Strong tubers, $25 \mathrm{c}$ each; $\$ 2.50$ per doz.
DR MUIR (1902)-Another new cactus Dahlia well worthy of a place in the front rank of any garden or catalogue. It originated with me the same year as the Dr. Gates, and from the same parent plant. A most remarkably free bloomer. Flowers are large and full, with petals curved and twisted, giving a fluffy effect to the flower. The plant is dwarf and bushy in habit. Color, apricot. shaded to orange bronze.

Strong tubers, 25c each; $\$ 2.50$ per doz. 


\section{MRS. WINTERS, the Grandest of all White Dahlias}

NEWPORT, R. I., 1901. "Mrs. Winters was greatly admired and was very free. adooms $5-6$ inches and pure white." $5-6$ inches and pure

MARY BLUCK.

Colorado City, Colo. Nov. $23,1901$.

"Mrs. Winters is the best white Dahlia I have seen. It has never shown an open center with me, and the outer petals are always fresh and well preserved.

A. F. BISHOP.

PovghKeepsie, N, Y., 1901. "Mrs. Winters is a beauty. I have showed it to a number of my friends. All pronounce it a perfect Dahlia."

C. O. BEESMER.

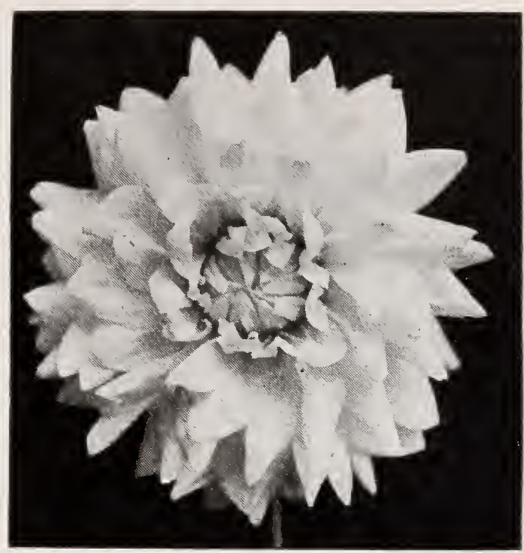

Colorado Springs. Colo. 'O1 "I consider M rs. Winters the finest white Dahlia of her class. You cannot recommend her too highly. She is grand beyond description.

C. E. PERRY.

Hillsboro, O., Nov. 1901. "Your Dahlias all proved to be extra fine, especially Mrs. Winters. Everyone who saw the blooms thought they were immense and perfect in every particular

MRS. J. A. LEMON.

Denver, Colo., 1901. "I think the new white Dahlia, Mrs. Winters, is the most beautiful of all Dahlias. Much superior to any , other white that I have seen.

ALICE G. VAN STONE.

Mrs. Winters. (ONE-FOURTH NATURAL SIZE.)

"In offering this Dahlia, I believe I am introducing the best White Danlia yet produced. The cleim is a large one, but I believe its merits will justify the claim.

I originated it three years ago, and have watched it carefully, and have yet to see the first imperfect flower. Its color is a pure waxy white, which slows no tint or variation even in the strongest sunlight. It blooms very freely, producing flowers from 5 to 7 inches in diameter, with beautifully pointed petals. . . . Another good quality is that it never shows an open center. The plant grows to a height of 3 feet, and is of a rather spreading habit, and in type belongs to the cactus section; but the petals, although pointed, are rather broad."

The above are my introductory notes of two years ago. And now, after two years' longer trial, I find no reason to change or modify the above. It is still the grandest of all White Dahlias. Price, $40 \mathrm{c}$ each, $\$ 4.00$ per dozen.

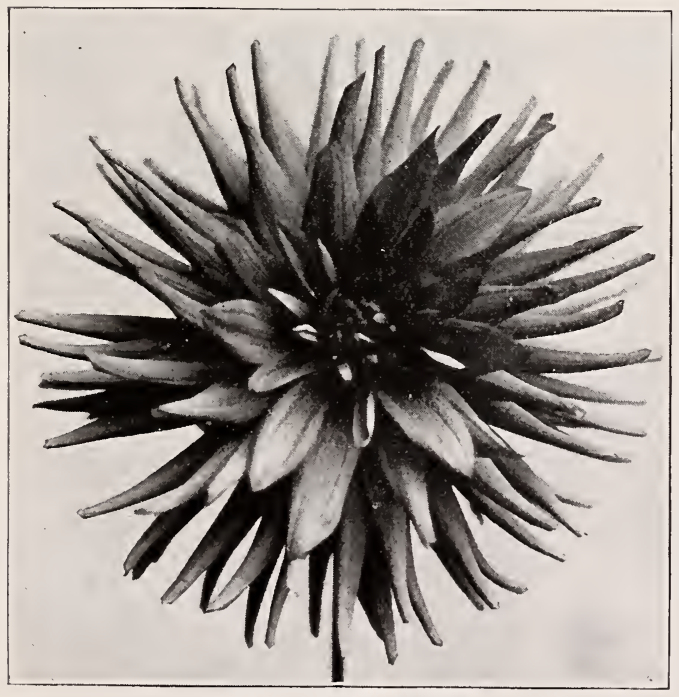

COUNTESS OF LONSDALE

COUNTESS OF LONSDALE. The freestflowering Cactus Dalılia in the collection, and perfect in form. Color, an exquisite shade of rich salmon, with just a suspicion of apricot at the base of the petals. Towards the tips the color deepens gradually to the softest carmine pink. (See cut.)

Price, 25c each, $\$ 2.50$ per dozen.

BRITANNIA. (Cactus.) The superb form and delicate coloring of this Dahlia entitles it to a place in every collection. Its petals are very long and regular. Color, salmon pink, shading to carmine.

Price, 25c each, $\$ 2.50$ per dozen.

\section{ARACHNE. (Cactus.)}

A most remarkable flower. The center of each petal is pure white edged along its entire length with broad band of brightest crimson. As, however, the edges of the petals are completely reflexed, the white only of the outer petals is seen when looking straight into the face of the flower, sideways the refleced crimson edges are fully visible, and give the flower a very elegant and coquettish appearance.

Price, 25c each, $\$ 2.50$ per dozen. 
HOHENZOLLERN. (Cactus.) In many respects this one is quite similar to Badenia. In shape of flower and habit of growth they resemble closely. Color clear orange, a shade lighter than Badenia, but has no rariegation.

Strong tubers, 25ะ each, $\$ 2.50 \mathrm{per}$ dozen.

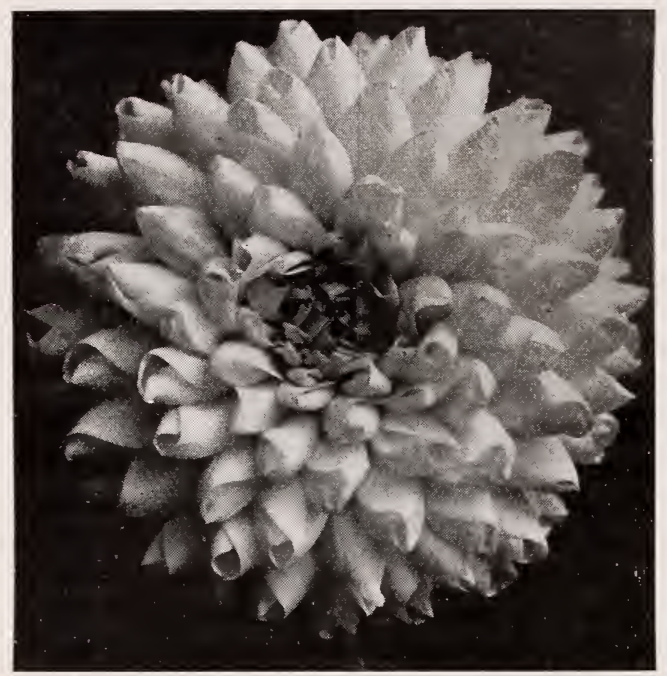

GRAND DUKE ALEXIS. A magnificent Dahlia of the largest size. Its petals are beautifully quilled. giving it a very unique appearance. Its color is pure white, if slightly shaded, but orerspread with delicate lavender when grown in bright sunlight. Undoubtedly one of the best of the show rarieties.

Price, 20c each, $\$ 2.00$ per dozen.

MRS. CHAS. TURNER. (Cactus.) This one is the finest of all the yellows in the cactus varieties. Extra large, with long, pointed petals, and perfect form. Bright lemon yellow.

Price, 2.5c each, \$2.50 per dozen.

GRAND DUKE ALEXIS

SPECIAL OFFER-One strong tuber of each of the foregoing eleren novelties for $\$ 3.50$.

\section{Classification of Dahlias}

Dahlias are divided into six general classes, and are amply illustrated on the back of this Catalogue.

Class r. Cactus.-This class embraces the long. narow-petaled rarieties, the petals of which are generally pointed or twisted.

Class 2. Decorative (so called for want of a better name). This class is an intermediate form, having broad, flat petals, and was formerly classed with the Cactus lists.

Class 3. Fancy.-This class takes in all rariegated rarieties.

Class 4. Pompon.-This class embraces the small, round Dahlias, the plants of which are generally of a dwarf, bushy habit. The lines for this class. however, are not clearly drawn.

Class 5. Show.-The name show generally applies to those varieties producing large, weli-formed flowers, shewing only solid colors, but may frequently have shaded tips.

Class 6. Singie.-Too wril known to require a description.

Note-There is of neersity more or less overlapping among the classes, and the above rules only apply in general. 


\section{CACTUS AND DECORATIVE VARIETIES \\ AND FORMS SEE LAST PAGE} FOR ILLUSTRATION

Strong Tubers. Prices, 15 cents each; $\$ 1.50$ per dozen, postpaid.

BLACK PRINCE. (Decorative.) Very large. Dark velvety maroon.........4 4 CLARA NISSEN (Decorative.) Vivid scarlet. Medium size. Excellent for cutting. CINDERELLA. (Cactus.) Petals long and pointed and quite regular in outline. Color, dark purple maroon. A very early and free bloomer.................. CHANCELLOR SWAYNE. (Cactus.) Tiolet purple. Quite perfect in outline.... 4 CACTUS QUEEN. (Decorative.) Pale silvery pink, suffused with light purple. Very large ...................6 6 COUNTESS OF PEMBROKE. (Cactus.)

Soft lilac, shaded to lavender........ 3

DENVER. (Decorative.) Pure yellow. Reverse of petals shaded orange bronze... 3

EARL OF PEMBROKE. (Cactus.) Deep purple maroon. Fine form.......... 3

GRAND MIOGUL. (Decorative.) Bright scarlet tipped and streaked pure white. 4 GERMANIA NORVA. (Decorative.) Color, bright pink; petals heavily serrated. (See light flower on trade mark)..... 3

GOLDEN COIN. (Decorative.) Old gold color, shading to golden bronze......4 4

GLORIOSA. (Cactus.) Bright scarlet, long curved petals. One of the best.......4

GERTRUDE. (Decorative.) Pale lemon; good form and stem............4

HENRY PATRICK. (Decorative.) Pure white. Flowers are very large and pure in color ...................6 6

JOHN ELITCH. (Decorative.) One of the grandest of Dahlias. Deepest red. Very long stem ................. 6

JENNIE PEARSE. A lovely yellow cactus of medium size, petals long and regular, curving forward. Early and free.. 3

JOHN H. ROACH. (Cactus.) Canary yellow, petals long and curved .......... 3

IING OF CACTUS. (Decorative.) A beautiful large red flower. Very long stem. . 6

LYNDHURST. (Decorative.) Scarlet or vernilion. A noble flower .......... 4
Ft. High, Approximate

LUCILE. (Decorative.) A remarkably free bloomer, so much so that the whole plant appears one mass of pure sulphur

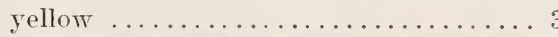

LADY PENZANCE. (Cactus.) Purest yellow, fine form, stems short.........

MAID OF KENT. (Decorative.) Intense scarlet, variegated with pure white; frequently a solid scarlet...........4

MRS. HARTONG. (Decorative.) Very large and of exquisite form. Color, light fawn, suffused with pink. Very handsome .................... 5

MRS. BENNETT. (Cactus.) Soft crimson, large and well formed, petals broad and pointed .................. 4

MRS. BARNES. (Cactus.) A beautiful primrose color. Flower well formed and a free bloomer. Stems rather short for cutting .................. 4

MYRTLE. (Decorative.) Very free flowering, of medium size. Color, vivid scarlet ...................

MRS. PEART. (Cactus.) One of the grandest of all cactus Dahlias. Color, a delicate creamy white............ 3

MATCHLESS. Another grand cactus Dahlia. Fetals long and even. Dark

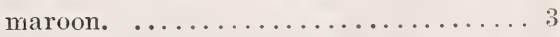

MAYOR HASKINS. (Cactus.) Bright scarlet. Petals long and curved. Tery large .................... 4

MRS. TAIT. (Decorative.) Pure white, petals deeply serrated. Good........4 4

MRS. LINDER. This new decorative Dahlia I consider one of my best. Its color is a beautiful creamy white, shading to blush pink. Of perfect outline..4

NYMPHAEA. (Decorative.) A pale pink flower of medium size. Very valuable for cutting purposes .............. 3

OURAY. (Decorative.) Deep blood red. Flower very large and rather loosely constructed. Stems very long........4 4 
Ft. High, Approximate

PRINCE OF ORANGE. (Cactus.) A beautiful true cactus form. In color a blending of apricot, orange and bronze. Tery free ........................ 3

SALISBURY WHITE. (Cactus.) Pure
Ft High, Approximate white. Flower below medium in size. Good form ..................... 3

YELLOW QUEEN. (Decorative.) Soft pale yellow, sometimes marked with white $\ldots \ldots \ldots \ldots \ldots \ldots \ldots \ldots \ldots \ldots \ldots \ldots \ldots$

SPECIAL OFFER-One each of the foregoing 36 Cactus and Decorative Dahlias for $\$ 4.00$, including express charges.

\section{SHOW AND FANCY VARIETIES}

SEE ILLUSTRATION OF TYPES AND FORMS ON LAST PAGE

Strong Tubers. Price, $15 \mathrm{c}$ each; $\$ 1.50$ per doz.

Ft High, Approximate

ANNIE MOORE. A fine rariegated flower of medium size. Color, a veautiful combination of cherry, pink and white .... 3

A. L. CHASE. Creamy white, streaked with purple; sometimes solid purple.... 3

A. D. LIVONI. Rich pink. Finely formed. A very handsome flower .......... 3 AUSTRIAN. Buff ground, shaded to reddish pink at top. Large and full..... 5

ARABELLA. A large, perfect form. Pale lemon, shading to primrose at the tips.

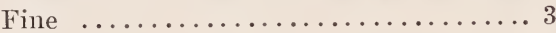

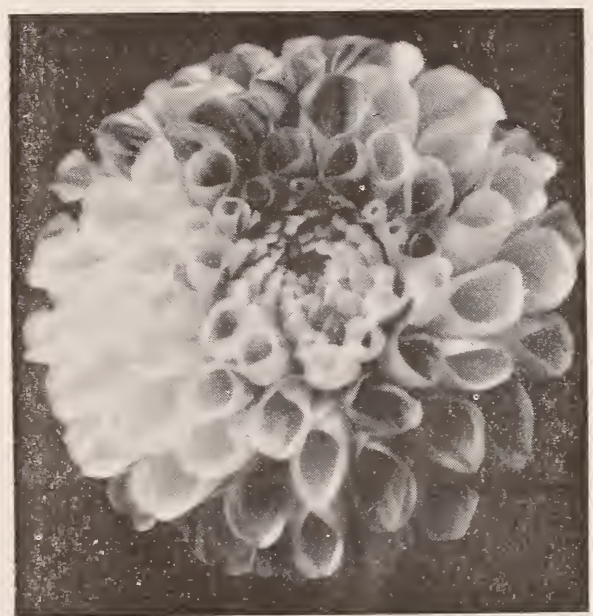

BON MAZA

BON MAZA. (Uncertainty.) An old Dahlia, but one of the best. White ground, streaked and marbled in a curious mamner with bright red........ 4

BEAUTY. A beautiful pure white. Large and full. One of the best of all the whites $\ldots \ldots \ldots \ldots \ldots \ldots \ldots \ldots \ldots$
Ft. High, Approximate

BON TON. A fine ball-shaped flower of a deep garnet red; sometimes tipped and streaked with white. An extra fine Dahlia .................. 4

CHIPETA. A bold, dark red flower. Tery large and full. Borne on long stems and flowering well above the foliage ......4 4 CRIMSON KIING. Deep crimson. Tery constant in color. An early and free bloomer .................... 3

ELDORADO. Rosy purple.

FLORENCE WOOD. Ros y pink. Large and exceptionally well formed, with good stem ..................... 3

FLORAL PARK JEWEL. Rich purple red, tipped and striped with white. Sometimes solid color. Tery early and free. . 3

FANCY. The foliage of this variety is hearily marked and variegated with white, giving a very pleasing effect. Flowers light red................ 4

CURIO. Deep orange bronze. Petals finely quilled. Generally blooms in cĩuster's of three. A fine Dahlia .............. 4

FANNY PURCHAS. Clear golden yellow. Fine form ...................

GLORI DE LYON. Pure white. The largest white Dahlia in cultivation, almost round as a ball................ 3

GEN. CUSTER. Deep purple maroon; long stems and a very free bloomer... . 4 GE0. RAWLINS. Maroon. Fine form. A grand flower ...................

GOLDEN TREASURE. A beautiful burnt orange color. Flower large, well formed and full to the center............... 3

GOLIATH. Deep garnet red. Good for cutting ..................

KATE HASLAM. A beautiful soft pink. Petals beautifully quilled......... 3 
Ft. High, Approxim.ate

FRANI SMITH. Rich dark maroon. Generally tipped with pure white, shaded into pink. One of the best......... 5

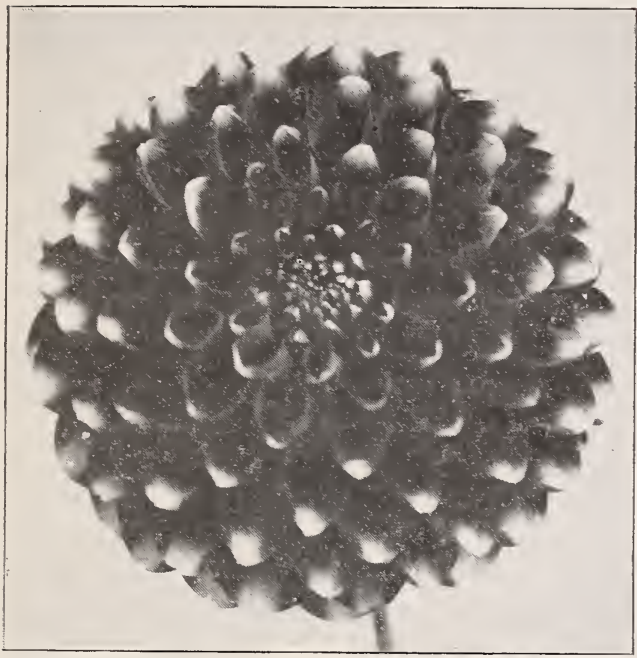

FRANK SMITH

IGNACIO. A remarkably healthy, stronggrowing plant, with long stems and large, full flowers. A deep, clear red... 4

JOHN FORBES. Fawn color, striped maroon. Very large and free, possessing all the properties of a first-class flower... . 3

KAISER WILHELM. One of the grandest flowers in cultiration. Of immense size and perfect form. Deep rellow, tipped and shaded witl cherry red .......4 4

LYDIA DIETER. A beautiful soft larender shade. One of the most attractive colors in the entire collection ........ 3

LONDON BEAUTY. Clear purple. Good form $\ldots \ldots \ldots \ldots \ldots \ldots \ldots \ldots \ldots$

LADY MILDMAY. A rery beautiful flower. Thite ground shaded to pale lilac. Tery large and full. A free bloomer ...................... 3

MISS DODD. Purest yeliow. Of exquisite form and color. A remankably handsome flower ................... 3
Ft. High, Approximate

MISS BROWNING. Clear yellow. tipped with white. Very fine ............4

MRS. LANGTRY. Light buff, tipped with crimson ........................ 3

MISS RUTH. Lemon rellow, tipped with pure white: sometimes clear rellow... 3

MRS. GLADSTONE. Pale soft pink, lovely color and form ..................

ORINE EMERSON. A rery handsome flower. borne on long stems. Color, rich dazzling red, shaded light cherry red... 3

ORANGE KING. Golden orange, shaded ochre. Stem long and good form...... 5

PEARL. Of immense size. with long stem. Color, pale lavender, shaded to lilac.... 3

PRINCESS MATHILDA. Pure white. So prolific that the whole plant appears one solid mass of white..............21\%

PIONEER. The nearest approach to a black Dahlia of any yet introduced. For combined excellence it has no superior. 21/2

PRINCE BISMARCK. Purple lake. A most pleasing color. Very fine form. One of the best ................. 3

PURPLE GEM. Rich roval purple, clear and coustant. This rariety is a decided improvement over the old varieties. A first-class flower.

PENELOPE. White ground shading to pale lavender................... 3

RED BIRD. Deep garnet red. Fine for cutting .........................

SNOWDRIFT. A well formed pure white flower, with long stems ........... 3

ST. ELMO. Dark purple. Long stem and fine llower ................. j

SNOW. A beautiful, pure white, long stems, excellent for cutting.........4 4

THE CARDINAL. Deep cardinal red. Stem long. Fine for cutting . . . . . . . . 4

VERIDIFLORA. Introduced from England, and is a natural curiosity. Its flomers are as green as the foliage, and are produced in profusion. For designing or decoratire work with other colors it has no equial. Plant dwarf and compact. An early bloomer ................ $2 \frac{1}{2}$

SPECIAL OFFER.-One each of the foregoing $4 \mathrm{~s}$ Show and Fancy Dablias for $\$ 5.00$, including express charges.

SECOND SPECIAL OFFER.-For one dollar, I will send a choice collection in thirteen separate varieties, my choice from the foregoing lists, including red, scarlet, white, yellow, variegated, etc. All good varieties. Prepaid for $\$ 1.00$. 


\section{POMPON OR BOUQUET LIST \\ FOR ILLUSTRATIONS OF TYPES AND FORMS SEE LAST PAGE}

Price, $15 \mathrm{c}$ each; $\$ 1.50$ per doz.

Ft. High, Approximate

CATHERINE. Bright yellow. Good form and stem $\ldots \ldots \ldots \ldots \ldots \ldots \ldots \ldots \ldots \ldots \ldots \ldots$

CAMELIAFLORA. Pure white. A perfect-

Iy formed fiower of medium size ..... 3

COMET. A pompon of rare attraction, producing an abundance of small balllike flowers, in color ranging from deep red to white .................. $31 \frac{1}{2}$

DAYBREAK. Rosy purple ........... 3

ELI MILARD. Blush whice. Quite small and well rounded. A prolific bloomer. . 3 HEDWIG POLWIZ. Tery free. Color, red and white $\ldots \ldots \ldots \ldots \ldots \ldots \ldots \ldots$

LILIAN. Tery sinall. Primrose shaded to pink ..................
Ft. Hish, Approximate

ISABEL. Termilion. Very fine.......4 LITTLE PRINCE. Quite small. Widely varied in color from deepest red to pinkish white ................ 3

LITTLE REX. Rosy pink. Long stems. Fine for cutting...............4 LOTTIE ECKFORD. Pale pink ground, streaked and mottled with red.......4 MIDGET. Pink shaded crimson. Fine form $\ldots \ldots \ldots \ldots \ldots \ldots \ldots \ldots \ldots$

PURITY. Pure white. Well rounded and full. A prolific bloomer ...........3 WHITE ASTER. (GUIDING STAR.) Pure white. Excellent for cutting. Petals fringed. .................. 4

\section{SPECIAL OFFER - One each of the 14 Pompons, including mail, \$1.60.}

\section{A N N A S Price, 10c acth $\$ 1.00$ per doz.}

As a decorative plant the Canna has no equal. Its immense foliage, of rarious shades of green and bronze, contrasting beautifully with the gorgeous bloscoms, which are produced in profusion. The in prored Cannas produce flowers as large as the Gladiolus. The following are extra fine varicties.

Ft. High, Approximate

AMERICA. Foliage fine glossy bronze, almost as if varnished. Flowers extra large, deep orange.............. 4

ALPHONSE BOUVIER. Green foliage.

Color, bright crimson. Large........4 4

AUSTRIA. Green foliage. Color, pure yellow, with light blotches of red in the throat $\ldots \ldots \ldots \ldots \ldots \ldots \ldots \ldots .4$

BRONZE BEAUTY. Beautiful dark foliage, with orange scarlet flowers.....3

DUKE OF MARLBOROUGH. The darkest camna known, a beautiful crimson maroon. Green foliage ............4

EGANDALE. Bronzy foliage and soft currant-red flowers .............. 4

FLORENCE VAUGHAN. A splendid rariety, vellow with bright red spots; one of the best of its class. Green foliage $\ldots \ldots \ldots \ldots \ldots \ldots \ldots \ldots \ldots \ldots \ldots \ldots$

ITALIA. Green foliage. Flowers bright red, bordered with golden yellow......4 4
Ft High, Approximate

J. C. VAUGHAN. Purple foliage; flower large. Color, clear, deep vermilionorange .................... 3

J. D. CABOS. 4 feet. Purplish green foliage. Color, distinct apricot ......... 3

KING PHILIP. This new canna I introduced in 1900, and it has given general satisfaction. Color, orange scarlet. dotted and veined with deep red, contrasting beautifully with its deep green foliage. ....................... 3

MADAM CROZY. 3 feet. Green foliage. Immense flower heads of the deepest vermilion, gold-bordered .......... 3

PAUL IMARQUANT. Foliage deep green; large flower of a deep salmon color... 4

PRESIDENT McKINLEY. Foliage rich green. Blooms crimson, w1th scarlet

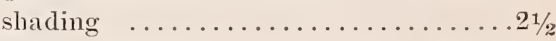

QUEEN CHARLOTTE. Bright scarlet, with a broad band of golden yellow in the centre of each petal. Green foliage.. 3

SPECIAL OFFER-The set of I5 varieties postpaid for \$1.25. 


\section{PAONIES}

It is surprising that so noble a flower, almost resembling the rose in brilliancy of color and perfection of bloom, should not be planted more. Amatelirs and dealers seen to have lost sight of the many improved varieties introdned within the last few years. The first point is their hardiness: in the sererest climate the plants require no other protection than that which they afford themselves. They thrive in almost every soil or situation, and when planted in large clumps make a magnificent display of flowers and foliage. Some of the varieties are very fragrant. The following eight varieties will, I am sme, prove very satisfactory:

\section{Price, 25c each; set for $\$ 1.25$.}

ALBIFLORA. A grand old Paeony ; pure white, very large and fragrant. Sometimes shows red streaks in the center.

EARLY ROSE. Early pink variety; blooms right after the Old Red; the flowers are large and in clusters.

HUMEI. A pink Paeony: very full and double; very large and showy: one of the latest in bloom. It wants to be mulched heavily in order to bring its flowers into perfection.

POTTSI. Dark purple red; rery long stem.
LATE ROSE. Similar to Early Rose, only it blooms later in the season. It is a fine rose-scented flower.

LADY LENORA BRAMWELL. Tery large and sweet. Silver rose.

OFFICINALIS RUBRA. (OId Red.) Flowers of a bright scarlet crimson. quite double and globular: rery earls, rare and fine.

GOLDEN CENTRE. This is not a large Paeony, but is a rery good one. Pure white, pale yellow center.

\section{GLADIOLUS}

GROFF'S STRAIN-The introduction of this popular strain of Gladioli marks a new epoch in Gladioli culture. It gave us new forms, new colors and a more rigorous growth. The colors are widely varied and wonderfully rich. I measured flowers during the past season full $5 \frac{1}{2}$ inches in diameter. In good soil the spikes will often grow to a height of 5 feet. As a cutflower they were immensely popular in this market last season and sold for double the price of the older stiains. I carry a fancy mixed strain in three sizes, all fine blooming corms.

First size, 10c each, $\$ 1.00$ per dozen.

Second size, $71 / 2 \mathrm{c}$ each, $7 \mathrm{c}$ per dozen.

Third size, je each. $50 \mathrm{c}$ per dozen.

\section{GLADIOLUS IN MIXTURE (WILMORE'S STRAIN)}

This Mixture is made up from fine rarieties, and are all selected first-class bulbs, and are sure to give the best resilts.

Price, toc per dozen, $\$ 2.00$ per 100 .

\section{TUBEROSE}

Teo well known to require a description. Plant in very rich soil and keep moist. If planted early it will bloom well out of loors.

Price, is each, $40 \approx$ per dozen. 


\section{Hardy Herbaceous Perennial Plants}

For Permanent Planting in Garden, Borders, Cemetery Plots, etc.

No flower garden is complete withont a collection of these most raluable plants. With a little care they may be selected so as to give a continuous supply of flowers from early spring to autumn's frosts. They repuire far less care than the amiuals or bedring plants, and may be used to good advantage to fill odd corners, along fences, and to screen minsighty objects. They are perfectly hardy, and yet for winter they should have a slight covering of leares or other litter. Care should also be taken to prerent pools of water standing on them during winter.

\section{BOLTONIA ASTEROIDES. (False Camomile.)}

Aster-like flowers, pure white and rery showy. Grows to a height of 4 and 5 feet. One of the best hardy peremnials. Price, $10 \mathrm{c}$ each; $\$ 1.00$ per dozen.

\section{BLEEDING HEART. (Dielytra Spectabilis.)}

A hardy perennial plant producing graceful sprays of heart-shaped pink and white flowers. Price, 25c each; $\$ 2.50$ per dozen.

\section{COREOPSIS LANCEOLATA.}

A beautiful, hardy border plant: grows 15 to 18 inches high, and produces its bright golden-yellow flowers in great profusion the entire season. It makes a handsome vase flower when cut, and should be grown in quantity whenerer flowers are wanted for table decoration.

Price, 10c each; $\$ 1.00$ per dozen.

\section{COLUMBINE.}

(Aquilegia.)

CAERULEA. The beautiful native species of the Rocky Mountains. Tery broad flowers, three inches or more in diameter. The outer sepals and long spurs are deep blue. Center of flower creamy white. Grand for cutting or border work. Price 25 cents each.

\section{CHRYSANTHA.}

(Golden Spurred Columbine.)

Grows two and half feet ligh, forming a bush two to three feet across, which is covered for two months with golden yellow flowers with long spurs; one of the most distinct of the family. Single, 10 cents each: $\$ 1.00$ per dozen.

\section{GOLDEN GLOW. \\ (Double Rudbeckia).}

This is decidedly one of the brightest and most showy among the hardy plants and of the easiest culture possible. The plant is compact, growing six to eight feet high, producing numerous stems which are laden with double golden-yellow flowers, in size and general appearance resembling a Cactus Dallia. Excellent for cut flowers, lasting well when cut. Should find a place in every garden. Price, 10c each; \$1 per dozen. 6 to 8 feet.

\section{GYPSOPHILA PANICULATA.}

(Baby's Breath.)

A beautiful perennial, possessing a grace not found in any other peremial, and attracting the eye of everyone. When in bloom it forms a symmetrical mass 2 to 3 feet in height, of minute pure white flowers, forming a beautiful gauze-like appearance. For cutting purposes it is exquisite, especially in combination with high-colored flowers, and some most lovely effec:s can be produced with it. Price, 10 cents each; $\$ 1.00$ per dozen.

\section{GAILLARDIA.}

(Grandiflora.)

Beginning to flower in June, they continue one mass of bloom the entire Summer. Flower 3 inches in diameter, center dark, reddish brown, petals vary from scarlet orange to crimson.

\section{HARDY ASTERS.}

(Michaelmas Daisies, or Star-worts.)

These are among the showiest of our lateflowering hardy plants, giving a wealth of bloom at a season when most other hardy flowers are past. I offer two colors only. Blue and White. Price, 10 cents each; $\$ 1.00$ per dozen. 


\section{HELIANTHUS.}

(Hardy Sunflowers.)

Multiflorus Maximus. A gigantic single variety, growing from 5 to 6 feet high, producing immense single golden-yellow flowers. Price, 10 cents each; $\$ 1.00$ per dozen.

\section{HIBISCUS.}

\section{(Crimson Eye.)}

An immense white flower with a crimson eye. Perfectly hardy. Blooms freely from mid-summer until killed by frost. Price, 10 cents each; $\$ 1.00$ per dozen.

\section{HARDY PERENNIAL PINKS.}

This old-time favorite is well deserving of a place in every garden. They occupy but little space, and yet produce a profusion of richly-hued flowers of delightful fragrance. Mixed colors, 10c each; $\$ 1$ per dozen.

\section{HEMEROCALLIS (FLAVA).}

\section{(Lemon Lily.)}

A most useful variety, growing about two feet high, with clusters of lily-like flowers of a rich sellow, exterior bronzy orange. 10 cents each; $\$ 1.00$ per dozen. 2 feet.

Kwanso. A double-flowering form and a most desirable herbaceous plant, that deserves being planted very largely; large orange-colored flowers shaded copper; blooms during July and August. 10c each, $\$ 1.00$ per dozen.

\section{HOLLYHOCKS.}

\section{(Double Strong Field Roots.)}

As a background in large borders or beds of the lower growing herbaceous plants there is nothing better. For planting in rows or groups on the lawn, or interspersing among shrubbery they are invaluable. The flowers, which are as elegant in shape as a Camelia, form perfect rosettes of the most lovely shades. Separate colors in red, white, yellow, pink and maroon, 10c each; $\$ 1.00$ per dozen.

\section{HOLLYHOCKS.}

(Mammoth Double-Fringed “Alleghany.")

An entirely new departure which has much to commend it. The mammoth flowers are wonderfully formed of looseiy arranged fringed petals, which look as if made from the finest China silk. Mixed colors, only $10 \mathrm{c}$ each; $\$ 1.00$ per dozen.

\section{IRIS (Germanica.)}

Large flowering varieties in blue, bronze, lavender, pink, yellow and creamy white. Separate colors 10 cents each, $\$ 1.00$ per dozen.

\section{HELENIUM (Sneeze-wort.)}

A fine late blooming plant, producing flowers of various colors of rellow and bronze, with brown centre. Continues in bloom after severe frost. Grows to a height of three feet. 10 cents each, $\$ 1.00$ per dozen.

\section{LYCHNIS (Lamp Flower.)}

A hardy perennial, growing to the height of $2 \frac{1}{2}$ to 3 feet, and producing fine heads of bright scarlet flowers. 10 cents each; $\$ 1.00$ per dozen.

\section{LILIES.}

TIGRINUM. (Tiger Lilı̣.) 10c each; $\$ 1.00$ per dozen.

FLORE PLENO. (Double Tiger Lily.) 10c each; $\$ 1.00$ per dozen.

\section{PHLOX (Perennial.)}

Too much could scarcely be said in praise of this, perhaps the most showy of all the hardy perennials. It is of the easiest culture, and a good selection of colors once planted will continue to produce a wealth of flowers for many years without further care. I carry the following distinct colors:
Deep Purple,
Pink,
Lilac,
Red,
Lavender.
Irlite.

Price, $10 \mathrm{c}$ each; $\$ 1.00$ per dozen; set for 50c, including mailage. 


\section{ORIENTAL POPPY.}

This poppy is perfectly hardy. Its large orange scarlet flowers make it one of the most showy of all plants. 10c each; $\$ 1.00$ per dozen.

\section{PLATYCODON GRANDIFLORA.}

\section{(Chinese Bell Flower.)}

Blooms freely from July to September. Flowers are bell-shaped and dark blue in color, quite hardy. Price, 10c each; $\$ 1.00$ per dozen.

\section{SWEET WILLIAM.}

Too well known to require description. A general farorite with all. Mixed colors, only strong plants. 10c each; $\$ 1.00$ per dozen.

\section{SHASTA DAISY.}

A mammotl new daisy producing pure white flowers with bright yellow centre. Flowers freely on long stems. Excellent for cutting. Perfectly hardy. Price 15c each; $\$ 1.50$ per dozen.

\section{SPIREA FILIPENDULA. \\ (Double Drop Wert.)}

A very hardy herbaceous plant, with fernlike foliage, throwing up numerous flower stems, literally corered with miniature double white flowers; very graceful. Price, 1 sc each; $\$ 1.50$ per dozen.

\section{HARDY SHRUBS AND VINES}

NOTICE-Articles in this department not marked * are intended for local trade, as they are too large for mailing. If ordered by express, purchaser pays the express charges. Articles marked * may be sent through the mail without extra cost.

\section{Hardy Climbing Plants}

\section{*AMPELOPSIS VEITCHI.}

The popular Boston or Japan Iry, which clings firmly to any wall, tree, etc. The leares, which at first are of an olive-green brown color, change to bright scarlet in the autumm. This variety becomes more popular every season, and is without question one of the very best climbing plants for corering brick, stone or wooderi walls that can be grown. Strong plants, 25e each.

\section{*CLEMATIS JACKMANI.}

This variety, with its strong, healthy gorwth, hardy nature and rich, deep relretypurple flowers, is the most satisfactory of its class. Blooms with astonishing profusion from July to November on shoots of the present season: should be pruned early in spring. T5c each.

\section{*CLEMATIS PANICULATA.}

A vine of very rapid growth, quickly corering trellises and arbors with handsome, clean, glossy green foliage. Flowers are of medium size, pure white, borne in immense sheets and of a most delicious and penetrating fragrance. The flowers appear in September, at a season when few other vines are in bloom. The extreme rapidity of growth, the showy foliage, beautiful and fragrant flowers and hardihood serve to make this one of the rery choicest of recent introductions. $20 \mathrm{c}$ each.

\section{HONEYSUCKLES.}

*HALlEANA. A vigorous grower; flowers rellowish-white; exceedingly fragrant and freely produced. $25 \mathrm{c}$ each.

*RED CORAL. Rapid grower, producing trumpet shaped red flowers; very hardy. 25c each. 


\section{*WISTARIA.}

A rery rapid climber, producing long sprays of purple flowers. Two-year-old roots, 25c each.

\section{*DEUTZIA (Lemoinei.)}

New. Its flowers are produced in broadbased, cone-shaped heads of from 20 to 30 flowers each, and are of the purest white; each, 25c.

\section{HYDRANGEA PANICULATA.}

This is the finest hardy Sinub in cultivation. The flowers, which are borne in dense prramidal panicles in the greatest profusion are white when they first open, but gradually change to rose color and remain in good condition for weeks. Two year old, $35 \mathrm{c}$

\section{LILACS.}

Named varieties. Double flowering.

\section{ALPHONSE LAVALLEE. Blue shaded violet.}

BELLE DE NANCY. Light rosy purple.

JEAN BAR'T. Rosy carmine.

LA TOUR AUVERGNE. Violet purple.

MAD. JULES FINGER. Satiny rose.

The above are in tree form, 3 feet high. Price, $60 \mathrm{c}$ each; the set of fire for $\$ 2.50$.

\section{COMIMON PURPLE.}

Price, 1 rear old, 15e.

Price, 2 years old, 25 c.

Price, 3 years old, 50c.

\section{COMMON WHITE}

Price, 1 vear old. 25c.

Price, 2 rears old, 35c.

Price, 3 vears old. 50c.

\section{PURPLE FRINGE.}

A beantiful, distinct, large shrub, much admired for its long fathery flower stalks, which give the tree the alparance of being covered with a clond of smoke. Four-reatrold trees only. Price. 50c each.

\section{SNOWBALL.}

Too well known to require description. Two years old, 50c ach. Gne rear old, mailing size, 25c each.

\section{TARTARIAN HONEYSUCKLE (Red)}

An erect symmetrical sluub. with glossy leaves, producing a profusion of star-shaped pink flowers, very hardy. *1 rear old, 25c; 2 -rear-olds, 50c

\section{SPIREA VON HOUTTE. (Bridal Wreath.)}

The grandest of all the spireas; it is a beautiful ornament for the lawn at any season, but when in flower it is a complete fountain of white bloom, the foliage hardly showing. Three-year-olds, $75 \mathrm{c} ; 2$-vear-olds, 50e; 1-year-olds, 25c.

\section{*SPIREA ARTHONY WATERER}

This spirea makes a dwarf, compact bush, 15 to 18 inches ligh, and is covered the entire growing season with large umbels of deep crimson flowers. It is perfectly hardy, an excellent plant for low clumps or beds. Price, 25c each.

\section{SYRINGA OR MOCK ORANGE.}

Vigorous growing, hardy shrubs, with fine pure white flowers and bright handsome foliage: should be more generally planted; very sweet. Price, *1 year old, 25c; 2 year old, $50 \mathrm{c}$. 


\section{HARDY ROSES}

TWO YeARS OLD, FIELD GROWN, 25C EACH, EXCEPT WHERE NOTED.

ALFRED COLOMBS. Bright cherry red. COQUETTE DES ALPS. Pure white; rery free.

GEN. JACQUEMINOT. Velvety crimson. MRS. JOHN LAING. Bright pink.
PAUL NEYRON. Rosy pink; very large.

PRINCE CAMILLE DE ROHAN. Dark velrety crimson.

SWEET BRIAR. Highly prized on account of the delightful fragrance.

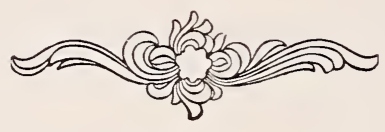

\section{Three Hardy Climbers}

BALTIMORE BELL. Blush white.

CRIMSON RAMBLER. Bright red; 50c.

PRAIRIE QUEEN. Rosy red.

Note-All of the above are hardy here, but should have slight protection for winter. 


\section{A FEW FACTS AND FANCIES About the Dahlia}

This interesting fower derives its name from Dr. Andrew Dahl, a noted Swedish botanist. The wild Dahlia is found in South America, and extends as far north as Mexi:o. There are but few species, but these have been propagated into a seemingly endless number of varieties of every hue. Just who should have the honor for first introducing the Dahlia as a domestic flower is a question upon which the authorities differ. But it is generally conceded that the first collection was sent to Madrid by Baron Humboldt, who was traveling in Mexico. They were first introduced into England in 1789, by the Marchioness of Bute, but they were grown in France and Spain several years prior to this. This collection, together with another receired in 180t, was lost. Another lot was imported in 1815, and from this collection most of the Dahlias of the present time have been propagated. The flowers embrace all colors excepi blue. in their wild state they are single.

But to speak of the Dahlia of the present: It is wonderful to note the changes, not only in the Dahlia itself, but in the popular attention paid to it. Especially is this true of some of the new cactus varieties, which, with their long twisted or pointed petals, remind me more of a Chrysanthemum than a Dahlia. But, however popular this new type may be with some, it is plainly evident that it will not supplant the old show and fancy types. It, however. should be borne in mind that the Cactus-Dahlia is still new, and it is quite probable that many of the weaknesses of the type may yet be eradicated. The capricious habit of the Dahlia to sometimes freak, and sport, has given rise to some popular delusions concerning them, as, for instance, drawing color froni other plants through the contact of the roots, and making variegated varieties by drawing various colored yarn threads through the roots, etc.; all such beliefs are without foundation in fact. It nust be admitted, however, that the laws governing these liabits are but little understood.

\section{CULTIVATION AND PROTECTION \\ (READ THIS BEFORE PLANTING)}

While the Dahlia is one of the easiest of all flowers to cultivate, it by no means follows that it requires no attention. In fact, no flower that I have ever cultirated will give such a generous response to good cultivation as the Dahlia. Deep and thorough stirring of the soil during the early growth of the plant is indispensable to success. With poor cultivation or neglect the flower will rapidly degenrate-become semi-double and faded in color. The Dahlia, with but few exceptions, should be given an open, sumny situation for at least a portion of each day. It is a rank feeder anil should be giren rich soil and kept free from grass and weeds. Cultivation should cease when the blooms appear. After this a liberal supply of water in dry weather wili be all they require. Plant the bulbs two or three feet apart, according to the size and habit of the plant. The bulbs should be planted four inches below the surface of the ground, laring the bulb on its side. Varieties growing about three feet in height should be tied to stakes to prevent falling. Plant about the first of May in this latitude. As soon as the frost has killed the foliage, the roots should be carefully taken from the ground and the soil shaken from among them; they may be stored away in a cool place, not too dry, but secure from frost.

\section{FLOWER AND VEGETABLE SEEDS}

I do not keep these in stock, but will gladly procure them from local dealers and send them withont extra cost to customers who may have need of them, under the guarantee of the dealer.

W. W. WILMORE, Dahlia Specialist. 
is:
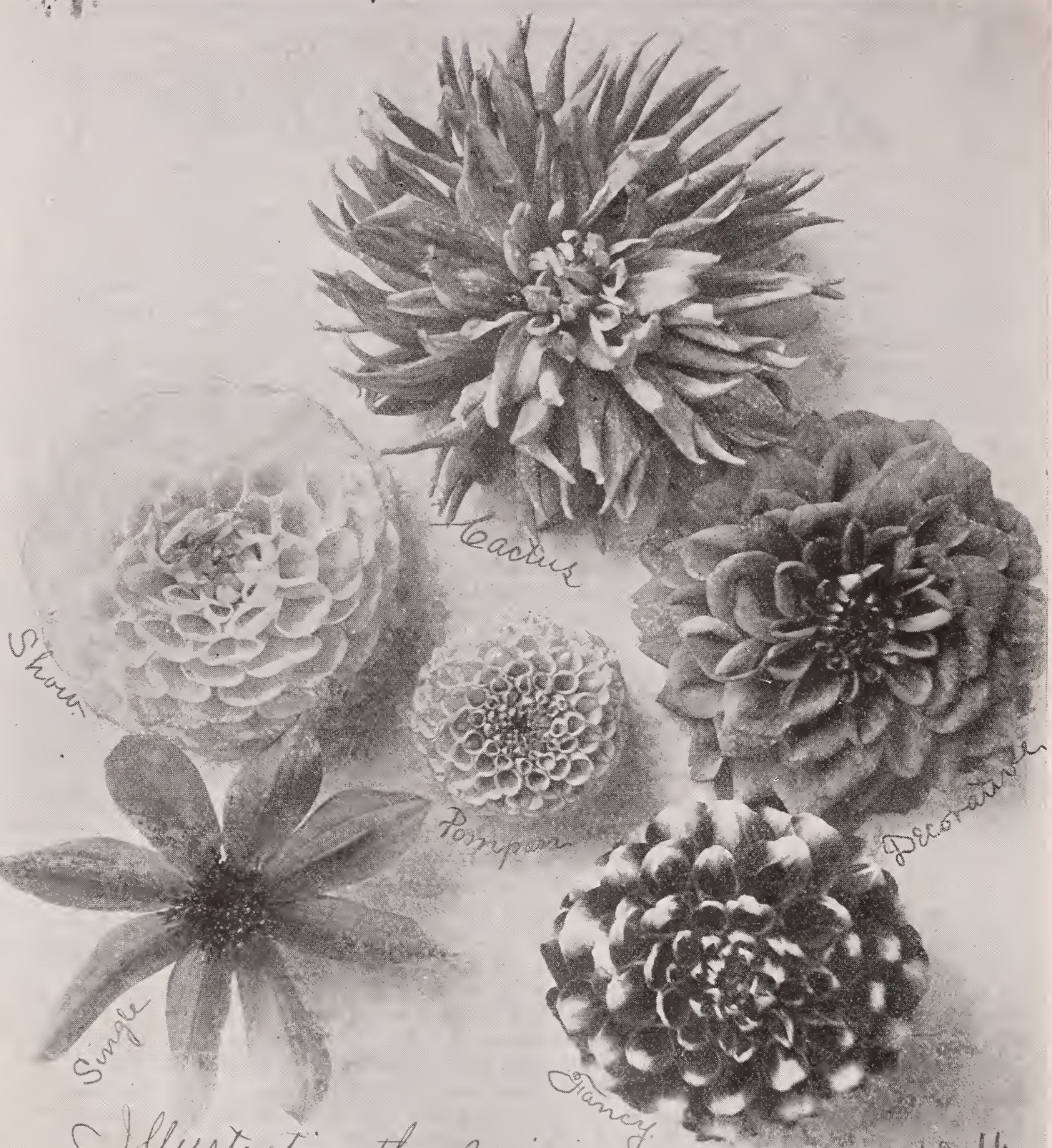
Clustrating the varivis types and forms of Dablias D. Dhenone Dinver Coli.

\section{S P R I N G 1903}

\section{W. W. WILMORE, Dahlia Specialist P. O. BOx 382 ....DENVER, COLO.}

